\title{
RNA:protein ratio of the unicellular organism as a characteristic of phosphorous and nitrogen stoichiometry and of the cellular requirement of ribosomes for protein synthesis Tatiana V Karpinets*1,4, Duncan J Greenwood ${ }^{2}$, Carl E Sams ${ }^{1}$ and John T Ammons ${ }^{3}$
}

\author{
Address: ${ }^{1}$ Department of Plant Sciences, University of Tennessee, 2431 Joe Johnson Drive. Knoxville, TN 37996-4561, USA, ${ }^{2}$ Warwick HRI, \\ Warwick University, Wellesbourne, Warwick, CV35 9EF, UK, ${ }^{3}$ Biosystems Engineering \& Environmental Science Department, University of \\ Tennessee, 2506 E. J. Chapman Drive, Knoxville, TN 37996-4531, USA and ${ }^{4}$ Computer Science and Mathematics Division, Oak Ridge National \\ Laboratory, P.O. Box 2008, MS6164, Oak Ridge, TN 37831, USA \\ Email: Tatiana V Karpinets* - karpinetstv@ornl.gov; Duncan J Greenwood - D.Greenwood@warwick.ac.uk; Carl E Sams - carlsams@utk.edu; \\ John T Ammons - ammonst@utk.edu \\ * Corresponding author
}

Published: 05 September 2006

BMC Biology 2006, 4:30 doi:10.1186/174I-7007-4-30

This article is available from: http://www.biomedcentral.com/I74I-7007/4/30

(c) 2006 Karpinets et al; licensee BioMed Central Ltd.

This is an Open Access article distributed under the terms of the Creative Commons Attribution License (http://creativecommons.org/licenses/by/2.0), which permits unrestricted use, distribution, and reproduction in any medium, provided the original work is properly cited.

\begin{abstract}
Background: Mean phosphorous:nitrogen (P:N) ratios and relationships of $\mathrm{P}: \mathrm{N}$ ratios with the growth rate of organisms indicate a surprising similarity among and within microbial species, plants, and insect herbivores. To reveal the cellular mechanisms underling this similarity, the macromolecular composition of seven microorganisms and the effect of specific growth rate (SGR) on RNA:protein ratio, the number of ribosomes, and peptide elongation rate (PER) were analyzed under different conditions of exponential growth.
\end{abstract}

Results: It was found that P:N ratios calculated from RNA and protein contents in these particular organisms were in the same range as the mean ratios reported for diverse organisms and had similar positive relationships with growth rate, consistent with the growth-rate hypothesis. The efficiency of protein synthesis in microorganisms is estimated as the number of active ribosomes required for the incorporation of one amino acid into the synthesized protein. This parameter is calculated as the SGR:PER ratio. Experimental and theoretical evidence indicated that the requirement of ribosomes for protein synthesis is proportional to the RNA:protein ratio. The constant of proportionality had the same values for all organisms, and was derived mechanistically from the characteristics of the protein-synthesis machinery of the cell (the number of nucleotides per ribosome, the average masses of nucleotides and amino acids, the fraction of ribosomal RNA in the total RNA, and the fraction of active ribosomes). Impairment of the growth conditions decreased the RNA:protein ratio and increased the overall efficiency of protein synthesis in the microorganisms.

Conclusion: Our results suggest that the decrease in RNA:protein and estimated P:N ratios with decrease in the growth rate of the microorganism is a consequence of an increased overall efficiency of protein synthesis in the cell resulting from activation of the general stress response and increased transcription of cellular maintenance genes at the expense of growth related genes. The strong link between P:N stoichiometry, RNA:protein ratio, ribosomal requirement for protein synthesis, and growth rate of microorganisms indicated by the study could be used to characterize the $\mathrm{N}$ and $\mathrm{P}$ economy of complex ecosystems such as soils and the oceans. 


\section{Background}

Although microorganisms are flexible in their nitrogen $(\mathrm{N})$ and phosphorus (P) content because of their ability to store these nutrients, the mean P:N ratios and their variations indicate surprising similarity among and within microbial species and even with plants and insect herbivores. For example, for marine phytoplankton, the variations in P:N ratio by mass are between 0.04 and 0.30 , with an overall average close to the Redfield ratio of 0.14 [1]. An average value of the ratio in terrestrial plants at their natural field sites is in the range $0.07-0.08$ [2-4]. Freshwater zooplankton and insect herbivores from terrestrial ecosystems also show similarity, with mean P:N ratios of 0.10 and 0.08 respectively [2].

Stoichiometric constraints are an important factor in the regulation of microbial growth and in their interaction with the environment. It has been proposed that an increase in the growth rate requires an increase in protein biosynthesis and, therefore an additional allocation of cellular resources to the synthesis of ribosomes and ribosomal RNA, which comprise the main part of cellular RNA. As a result of this allocation, the P:N ratio in the cell increases. This idea is referred to as the growth-rate hypothesis (GRH) [5-7]. In agreement with this hypothesis, the synthesis of rRNA in bacteria is maintained in proportion to the cell's requirement, and the number of rRNA genes correlate with the rate at which phylogenetically diverse bacteria respond to resource availability $[8,9]$. In marine bacteria, species-specific growth rates may be estimated by measuring the rRNA content of the organisms [10].

Ecological studies supporting the GRH usually consider $\mathrm{P}: \mathrm{N}$ stoichiometry, growth rate, and RNA content across different organisms. A significant effect of the growth rate of an individual unicellular organism on its macromolecular composition has also been well-documented [1116]. It was found that an impairment of growth in bacteria, yeast, algae, and fungi resulted in a decrease in their total RNA, rRNA, protein contents, and RNA:protein ratio. A direct proportionality between specific growth rate and RNA:protein ratio was reported in Escherichia coli [11]. This finding is in agreement with the GRH, because $\mathrm{N}$ and $P$ in RNA and proteins dominate the total amounts of these elements in cells of unicellular organisms [5]. We can conclude from these studies that some molecular mechanisms activated in the cells of an individual organism in response to environmental conditions may be responsible for changes in P:N stoichiometry. At present, however, these mechanisms are not clear. According to studies of translational efficiency in vitro $[17,18]$, the most rapid bacterial growth demands maximally efficient ribosomes. Because the number of ribosomes is proportional to cellular rRNA and RNA contents [19], the increased effi- ciency of protein synthesis by ribosomes under the faster growth reported in these studies may lead to a decrease in the RNA:protein ratio in the cell. However, this view is not in agreement with the GRH and is not supported by the aforementioned studies of macromolecular composition. In addition, studies of ribosomal, messenger, and transfer RNA in yeast during a nutritional shift [20] show that, although ribosomal RNA is significantly reduced after growth inhibition, messenger and transfer RNA are slightly increased [21]. These observations give indirect support to the notion that synthesis of proteins in microorganisms under growth impairment may require fewer ribosomes than under favorable growth, leading to a decrease in RNA:protein and P:N ratios. This cellular regularity may underlie the effect of growth rate on RNA:protein and P:N ratios at the level of an individual organism. The objective of this study was to investigate this hypothesis and to show that the cellular P:N ratio estimated from the RNA:protein ratio reproduces mean P:N ratios obtained experimentally for diverse microorganisms and plants. We analyzed macromolecular composition, number of active ribosomes, and peptide elongation rate in a set of unicellular prokaryotic and eukaryotic organisms (bacteria, yeast, fungi, algae) as functions of their growth rates. This information was used to calculate P:N stoichiometry of unicellular organisms and the cellular requirement of ribosomes for protein synthesis in different growth conditions.

It was found that the estimated P:N ratios derived from the RNA and protein contents of these organisms were in the same range as mean ratios reported for other, diverse organisms. There was a direct proportionality between the ribosomal requirement for protein production in the cell and RNA:protein ratio, which may underlie this similarity and the positive relationship of $\mathrm{P}: \mathrm{N}$ ratio with the growth rate of the microorganisms. A decrease in the ribosomal requirement for protein production with an increase in the growth rate could be explained in terms of the disposal soma theory.

\section{Results \\ P:N ratios calculated from RNA and protein contents of the unicellular organisms are in the same range as found in the primary producers and have similar relationships with growth rate}

Experimental data for the analysis were obtained from previous studies of macromolecular composition (protein and RNA contents) of bacteria (E. coli, Streptomyces coelicolor, Mycobacterium bovis, Selenomonas ruminantium), budding yeast (Saccharomyces cerevisiae; two studies), fungi (Neurospora crassa) and algae (Prototheca zopfii) (Table 1). The studies are referred to by the name of the organism. 
Table I: Variation of the macromolecular composition, $\mathbf{P}$, and $\mathbf{N}$ contents of the unicellular organisms in the studies

\begin{tabular}{|c|c|c|c|c|c|c|c|c|c|}
\hline Organism & Ref. & $\begin{array}{c}\text { Number of } \\
\text { growth } \\
\text { conditions, and } \\
\text { temperature } \\
\left({ }^{\circ} \mathrm{C}\right)\end{array}$ & SGR & mRNA (fg)c & $m_{P r}(f g)$ & $\mathbf{R}_{\mathrm{RNA}: \mathrm{Pr}}$ & $P$ (fg) & $N(f g)$ & $\mathbf{R}_{\mathrm{P}: \mathbf{N}}$ \\
\hline Escherichia coli & {$[\mathrm{II}]$} & $5(37)$ & $0.42-1.73$ & $20-212$ & $100-450$ & $0.2-0.47$ & $1.6-16.9$ & $20.2-109.1$ & $0.08-0.15$ \\
\hline $\begin{array}{l}\text { Streptomyces } \\
\text { coelicolor }\end{array}$ & [II] & $7(30)$ & $0.024-0.3$ & $30.9-85.7$ & $144-170$ & $0.21-0.5$ & $2.5-6.9$ & $29.4-42.1$ & $0.08-0.16$ \\
\hline $\begin{array}{l}\text { Mycobacterium } \\
\text { bovis }\end{array}$ & {$[11]$} & I (37) & 0.029 & 13.2 & 153 & 0.09 & 1.1 & 28.3 & 0.04 \\
\hline $\begin{array}{l}\text { Selenomonas } \\
\text { ruminantium }\end{array}$ & {$[12]$} & $3(39)$ & $0.05-0.35$ & $53.9-87.2^{b}$ & $300-423^{2}$ & $0.18-0.21$ & $4.3-7.0^{\mathrm{b}}$ & $51.6-72.8^{b}$ & $0.072-0.08$ I \\
\hline $\begin{array}{l}\text { Saccharomyces } \\
\text { cerevisiae (I) Strain } \\
\text { FL52 Id }\end{array}$ & [13] & $6(30)$ & $0.04-0.59$ & $600-1400$ & $1900-3040$ & $0.2-0.47$ & $48-112$ & $417-730$ & $0.12-0.15$ \\
\hline $\begin{array}{l}\text { Saccharomyces } \\
\text { cerevisiae (2) Strain } \\
\text { A364A }\end{array}$ & [14] & $8(30)$ & $0.085-0.43$ & $490-510$ & $2100-3500$ & $0.15-0.23$ & $39-41$ & $435-680$ & $0.06-0.09$ \\
\hline Neurospora crassa & {$[15]$} & $8(30)$ & $0.09-0.63$ & $15-62.8^{a}$ & $132-145^{a}$ & $0.11-0.43$ & $5-1.2^{\mathrm{a}}$ & $25-34.4^{a}$ & $0.05-0.15$ \\
\hline Prototheca zopfii & {$[16]$} & $12(25)$ & $0.086-0.223$ & $2200-15610$ & $10000-55000$ & $0.22-0.28$ & $176-1249$ & $2050-11802$ & $0.09-0.13$ \\
\hline All organisms & & & $0.029-1.73$ & $13.2-15610$ & $100-55000$ & $0.1-0.5$ & $1.1-1249$ & $20.2-11802$ & $0.04-0.16$ \\
\hline $\begin{array}{l}\text { Change by a factor } \\
\text { of: }\end{array}$ & & & 60 & 1183 & 550 & 5 & 1135 & 584 & 4 \\
\hline
\end{tabular}

aExpressed as $\mathrm{w} / \mathrm{w}$.

bexpressed as $\mathrm{mg}$ per $\mathrm{ml}$.

cl $\mathrm{fg}=10^{-15} \mathrm{~g}$.

dFL52I strain of S.cerevisiae carries a mutation and cannot synthesis pyrimidine endogenously, therefore the nucleotides were provided in the growth media.

The masses of RNA and proteins in the studies were determined under different conditions of exponential growth characterized by a range of specific growth rates (SGR). This parameter is a measure of the number of divisions per cell per unit time. Between 1 and 12 growth conditions were considered in each study (Table 1), with SGR varying from 0.029 to 1.73 per hour. The variation was created by the use of different growth media. The P:N ratios calculated from RNA and protein contents in the studied organisms growing in such diverse conditions were in the range $0.04-0.16$, with an average value of 0.1 (Table 1). This range of values was similar to that of the mean P:N ratios of the different organisms discussed in the introduction. The different growth conditions analysed in the study resulted in changes in P:N ratios in the microorganisms by factors of 5 and 4 only, whereas the range of each nutrient varied by three orders of magnitude (Table 1, columns 5-10). Smaller changes in P: $\mathrm{N}$ ratio at the organism level may be demonstrated by expressing the growth rate of the organisms as the relative growth rate (RGR). This parameter is often used in ecological studies [7], and is calculated as

$\mathrm{RGR}=\mathrm{SGR} / \mathrm{SGR}_{\max }$

where $\mathrm{SGR}_{\max }$ is the maximum SGR of the organism in the study. Figure 1 and Table 2 illustrate the effect of RGR on P:N ratio.
In all organisms, except the algae P. zopfii and S. ruminantium, an increase in growth was accompanied by a linear increase in RNA:protein ratio (Figure 2) and P:N ratio (Figure 1). The ratios in P. zopfii showed no correlation with growth (Table 2), possibly because the RNA:protein ratio varied only within the narrow range $0.22-0.28$, which corresponds to $0.09-0.13$ for the P:N ratio. The study of $S$. ruminantium included only three growth conditions, and, similarly to $P$. zopfii, the P:N ratio of the organism varied only slightly (from 0.072 to 0.081 ). In agreement with the GRH, the P:N ratio calculated from RNA and protein contents increased with an increase in the specific growth rate of the unicellular organism. The rate of increase in P:N ratio per unit of RGR, which was estimated as the slope of the regression line (Table 2), varied among the unicellular organisms, from 0.06 in E. coli to 0.28 in $S$. coelicolor. The intercept of the regression line on the ordinate also varied among organisms, even between different strains of $S$. cerevisiae. Considering the strong correlations between P:N ratios and RGR for most organisms, demonstrated by Figure 1, the regression intercepts may characterize the $\mathrm{P}: \mathrm{N}$ ratios required to maintain organisms in the stationary state.

\section{The cellular requirement of ribosomes for protein production in microorganisms may be estimated by the}




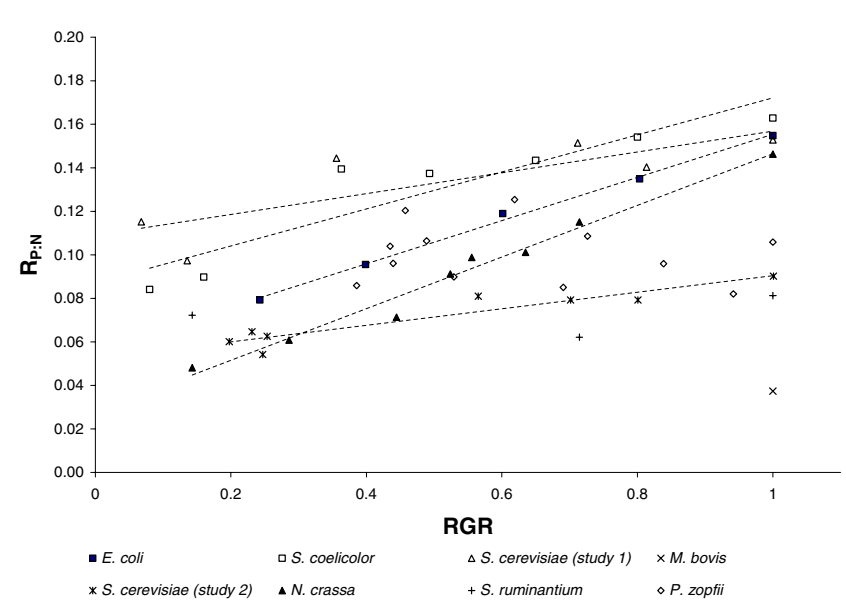

Figure I

The effect of relative growth rate on $P: N$ ratio inthe organisms. Relationships for $P$. zopfii and $S$. ruminantium are not presented by lines because of low correlation between the ratios and growth rates.

RNA:protein ratio using a common constant characterising protein synthesis machinery in the cell

The mass of ribosomal RNA per cell $\left(\mathrm{m}_{\mathrm{rRNA}}\right)$ measured in the studies of E. coli, S. coelicolor, M. bovis, S. cerevisiae (two studies), and N. crassa (Table 3 ) allowed us to estimate the cellular requirement of ribosomes for protein synthesis in the organisms as functions of the growth conditions by calculating the number of ribosomes and the peptide elongation rate (PER). By definition, PER is the number of amino acids incorporated into the peptide chain per second by one active ribosome. Therefore, it was calculated as the rate of protein synthesis in the cell expressed in amino acids per second divided by the number of active ribosomes, or algebraically as

$$
P E R=n_{a a} \times S G R /\left(F_{R a} \times n_{R}\right)
$$

where $\mathrm{F}_{\mathrm{Ra}}$ is the fraction of active ribosomes (involved in protein synthesis), $\mathrm{n}_{\mathrm{aa}}$ is the cellular protein content expressed in amino-acid equivalents, SGR is the specific

Table 2: Parameters of linear relationships between the $P: N$ ratio in the organisms and their relative growth rate $\left(R_{P: N}=\right.$ $a \cdot R G R+b)$

\begin{tabular}{lccc}
\hline Organism & $\mathbf{a}$ & $\mathbf{b}$ & $\mathbf{R}^{\mathbf{2}}$ \\
\hline Escherichia coli & 0.0573 & 0.0562 & 0.99 \\
Streptomyces coelicolor & 0.2837 & 0.087 & 0.85 \\
Selenomonas ruminantium & 0 & 0.068 & 0.09 \\
Saccharomyces cerevisiae (study I) & 0.0813 & 0.1089 & 0.67 \\
Saccharomyces cerevisiae (study 2) & 0.0887 & 0.0523 & 0.88 \\
Neurospora crassa & 0.1883 & 0.0278 & 0.98 \\
Prototheca zopfii & 0 & 0.1 & 0.02
\end{tabular}

growth rate expressed per second, and $n_{R}$ is the number of ribosomes per cell.

The number of ribosomes per cell is estimated from $m_{\mathrm{RNA}}$ by the equation

$$
\mathrm{n}_{\mathrm{R}}=\mathrm{F}_{\mathrm{rRNA}} \times \mathrm{m}_{\mathrm{RNA}} \times \mathrm{N}_{\mathrm{a}} /\left(\mathrm{M}_{\text {nucl }} \times \mathrm{n}_{\text {nuclR }}\right),
$$

where $\mathrm{F}_{\mathrm{rRNA}}$ is the fraction of ribosomal RNA in $\mathrm{m}_{\mathrm{RNA}}$ calculated as the ratio $\mathrm{m}_{\mathrm{rRNA}}$ and $\mathrm{m}_{\mathrm{RNA}}, \mathrm{N}_{\mathrm{a}}$ is Avogadro's constant, $M_{\text {nucl }}$ is the average mass of the nucleotide, and $\mathrm{n}_{\text {nuclR }}$ is the number of nucleotides per ribosome.

To characterize the cellular requirement of ribosomes for protein synthesis under different growth conditions, we calculated the increase in SGR per unit increase in PER, i.e. the ratio SGR:PER $\left(\mathrm{R}_{\mathrm{SGR} \text { PER }}\right)$. From equation 1, the following expression for this ratio was obtained:

$$
\mathrm{R}_{\mathrm{SGR}: \mathrm{PER}}=\left(\mathrm{F}_{\mathrm{Ra}} \times \mathrm{n}_{\mathrm{R}}\right) / \mathrm{n}_{\mathrm{aa}}
$$

According to this equation, $\mathrm{R}_{\mathrm{SGR} \text { PER }}$ measures the number of ribosomes in the cell required to incorporate one amino acid into a new protein. The reciprocal of this parameter (PER:SGR) is a measure of how efficiently synthesized ribosomes are used in the cell for protein production. In addition to the intrinsic translational efficiency of ribosomes, which may be estimated by studies of translation in vitro $[22,23]$, this parameter also includes the effects of cellular environment on the stability of mRNA, proteins and ribosomes. Therefore, the SGR:PER ratio gives an indirect estimate of the overall efficiency of cellular protein synthesis in vivo. It makes the parameter more suitable for estimating the effect of growth conditions on the efficiency of protein-production machinery of the microorganism. Values of $\mathrm{R}_{\mathrm{SGR} \text { PER }}$ in the microorganisms calculated in the studies are summarized in Table 3. Figure 3 presents experimental evidence for a close correlation $\left(R^{2}=0.98\right)$ between the values of $\mathrm{R}_{\mathrm{SGR}: \text { PER' }}$ which characterizes the ribosomal requirement for protein production, and the RNA:protein ratio $\left(\mathrm{R}_{\mathrm{RNA}: \mathrm{Pr}}\right)$. Moreover, this relationship has the same coefficient of proportionality for all organisms and growth conditions, referred to below as the C value.

Next we considered which cellular parameters are responsible for the identified proportional relationship between $\mathrm{R}_{\mathrm{SGR} \text { PER }}$ and the RNA:protein ratio. Substitution of equation 2 into equation 3 gives

$$
\mathrm{R}_{\mathrm{SGR}: \text { PER }}=\mathrm{F}_{\mathrm{Ra}} \times \mathrm{F}_{\mathrm{rRNA}} \times \mathrm{m}_{\mathrm{RNA}} \times \mathrm{N}_{\mathrm{a}} /\left(\mathrm{M}_{\text {nucl }} \times \mathrm{n}_{\text {nuclR }} \times \mathrm{n}_{\mathrm{aa}}\right)
$$

Considering $\mathrm{n}_{\mathrm{aa}}=\mathrm{m}_{\operatorname{Pr}} \times \mathrm{N}_{\mathrm{a}} / \mathrm{M}_{\mathrm{aa}}$, where $\mathrm{M}_{\mathrm{aa}}$ is the average mass of the amino acid, the equation underlying the pro- 
Table 3: Variation in the peptide chain elongation rate (PER), the number of active ribosomes in the cell per one amino acid in the synthesised proteins $\left(R_{\text {SGR:PER }}\right)$ and the fraction of rRNA in total RNA $\left(F_{\text {rRNA }}\right)$ in the studies

\begin{tabular}{|c|c|c|c|c|}
\hline \multirow[t]{2}{*}{ Organism } & \multirow{2}{*}{$\begin{array}{c}\text { PER, amino acids per second per } \\
\text { ribosome }\end{array}$} & \multirow{2}{*}{$\begin{array}{c}\mathbf{R}_{\mathrm{SGR}: \text { PER }}, \times 10^{-5} \text { ribosomes per } \\
\text { amino acids }\end{array}$} & \multicolumn{2}{|c|}{$F_{\text {rRNA }}$} \\
\hline & & & Range & Mean value \\
\hline I & 2 & 3 & 4 & 5 \\
\hline Escherichia coli & $|2-2|$ & $0.97-2.29$ & $0.85 I-0.866$ & 0.856 \\
\hline Streptomyces coelicolor & $0.59-3.17$ & $1.13-2.63$ & $0.85 I-0.858$ & 0.855 \\
\hline Mycobacterium bovis & 2.0 & 0.40 & 0.875 & 0.857 \\
\hline Saccharomyces cerevisiae (2 studies) & $2.8-10.0$ & $0.69-1.20$ & $0.81-0.82$ & 0.82 \\
\hline Neurospora crassa & $5.35-8.02$ & $0.47-2.18$ & $0.694-0.884$ & 0.857 \\
\hline Range (all the organisms) & $0.59-21$ & $0.40-2.63$ & $0.69-0.88$ & $0.82-0.857$ \\
\hline Change by a factor of & 36 & 6.5 & 1.3 & 1.0 \\
\hline
\end{tabular}

portional relationship between $\mathrm{R}_{\mathrm{RNA}: \mathrm{Pr}}$ and $\mathrm{R}_{\mathrm{SGR} \text { PER }}$ demonstrated in Figure 3 may be expressed as

(5) $\quad \mathrm{m}_{\mathrm{RNA}} / \mathrm{m}_{\mathrm{Pr}}=\left(\mathrm{M}_{\mathrm{nucl}} \times \mathrm{n}_{\mathrm{nuclR}}\right) /\left(\mathrm{F}_{\mathrm{Ra}} \times \mathrm{F}_{\mathrm{rRNA}} \times \mathrm{M}_{\mathrm{aa}}\right) \times$ $\mathrm{R}_{\text {SGR:PER }}$

or

(6) $\mathrm{R}_{\mathrm{RNA}: \mathrm{Pr}}=\mathrm{C} \times \mathrm{R}_{\mathrm{SGR}: \mathrm{PER} \text {, }}$

where

(7) $\mathrm{C}=\left(\mathrm{M}_{\text {nucl }} \times \mathrm{n}_{\text {nuclR }}\right) /\left(\mathrm{F}_{\mathrm{Ra}} \times \mathrm{F}_{\mathrm{rRNA}} \times \mathrm{M}_{\mathrm{aa}}\right)$.

If the left-hand masses of RNA and proteins in equation 5 are expressed in nucleotide and amino-acid equivalents, respectively, then

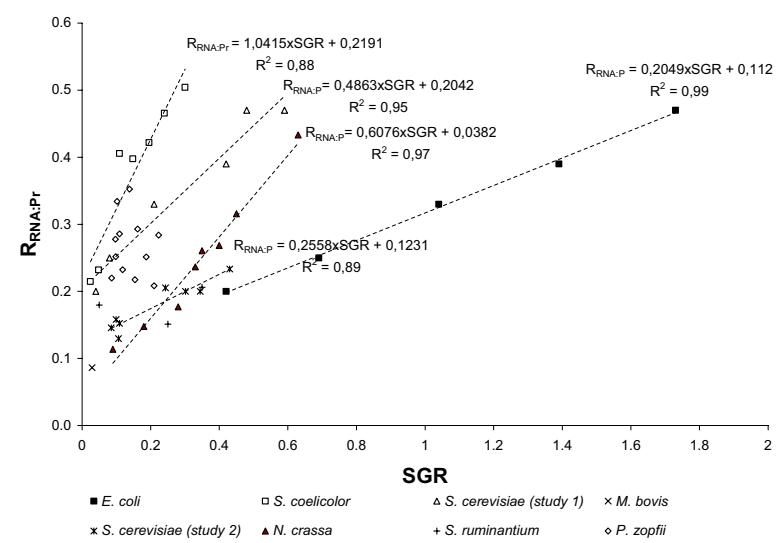

\section{Figure 2}

The effect of specific growth rate on RNA:protein ratio in the organisms. Relationships for $P$. zopfii and $S$. ruminantium are not presented by lines because of low correlation between the ratio and specific growth rate.
(8) $\quad \mathrm{C}=\mathrm{n}_{\text {nuclR }} /\left(\mathrm{F}_{\mathrm{Ra}} \times \mathrm{F}_{\mathrm{rRNA}}\right)$.

Equations 7 and 8 represent an analytical expression for the $\mathrm{C}$ value found in the experimental observations and demonstrated by Figure 3. Separate quantification of each parameter in equation 7 helps explain the characterization of the ribosomal requirement for protein production by the RNA:protein ratio for different microorganisms and growing conditions.

- $\mathrm{M}_{\text {nucl }}$ and $\mathrm{M}_{\mathrm{aa}}$. The average masses of nucleotide and amino acid in equation 7 are about 330 and $120 \mathrm{Da}$ respectively and are about the same in different organisms.

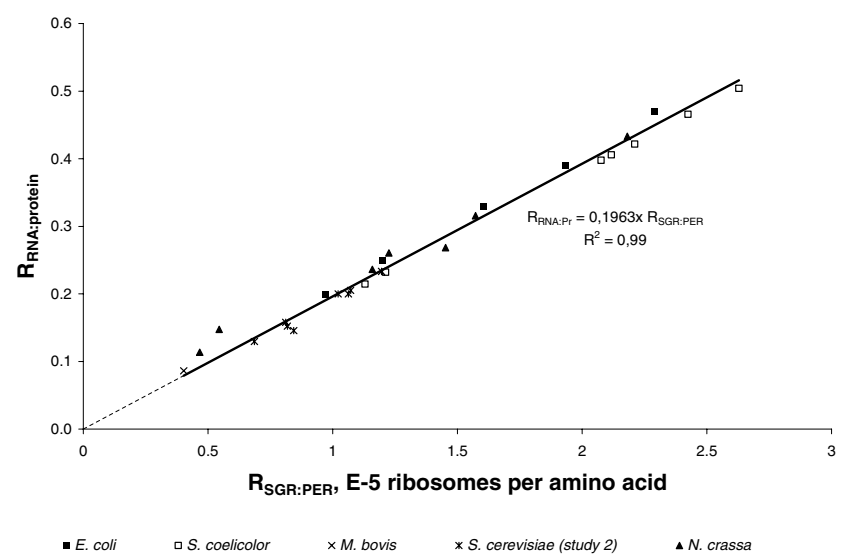

Figure 3

The proportional relationship between the RNA:protein ratio and the number of active ribosomes per synthesized proteins. The slope of the line is equal to the $C$ value in equations $6-8$. The mass of ribosomal RNA was not measured in studies of $S$. ruminantium and $S$. cerevisiae (one study), therefore only five species are considered. 
- $\mathrm{n}_{\text {nuclR }}$. The transcripts of ribosomal subunits also have high sequence similarity. The number of nucleotides comprising the ribosome, parameter $\mathrm{n}_{\text {nuclR }}$, is rather conservative across a wide range of species. Only small differences in the size of rRNA in different bacteria have been reported [24]. The 16S rRNA varies between $1487 \mathrm{bp}$ for the cyanobacterium Anacystics nidulans and $1549 \mathrm{bp}$ for Bacillus subtilis. The size of the 23S rRNAs is in the range $2876 \mathrm{bp}$ for A. nidulans to $3122 \mathrm{bp}$ for Mycobacterium leprae. The $5 \mathrm{~S}$ rRNAs are quite small, with an average size of $120 \mathrm{bp}$ and a range extending from $107 \mathrm{bp}$ in Mycoplasma capricolum to 123 bp in Deinococcus radiodurans. In summary, the average value for $\mathrm{n}_{\text {nuclR }}$ is 4632 nucleotides.

- $\mathrm{F}_{\mathrm{rRNA}}$. It is believed that the rRNA fraction of total RNA is independent of the growth rate. Specifically, it was shown that in E. coli, synthesis of rRNA and tRNA are controlled by similar promoters, so that rRNA and tRNA represent $86 \%$ and $14 \%$, respectively, of total stable RNA [25]. Although there are differences between eukaryotic and bacterial ribosomes in RNA sequences and in structure (bacterial ribosomes have two ribosomal RNA molecules, whereas eukaryotes have three), studies of the amount of ribosomal and total RNA in yeast showed that rRNA constituted about $85 \%$ of total RNA. This fraction decreased only slightly (to about $83 \%$ ) with decreasing growth rate [13]. The calculation of rRNA as a fraction of total RNA in the organisms under consideration (Table 3, rows 4 and 5) also shows small variation in this parameter (from 0.82 to 0.86 ) with an average value of 0.85 .

- $\mathrm{F}_{\mathrm{Ra}}$. A messenger RNA that is being actively translated usually has multiple ribosomes forming a polysome. Translationally inactive mRNAs are often sequestered in messenger ribonucleoprotein particles or associated with a single ribosome. According to experimental observations, the number of ribosomes in the cell is approximately one order of magnitude greater than the number of RNA molecules, but only $10-20 \%$ is free and available to initiate translation. The remaining ribosomes are engaged in translation and form polysomes [26]. It is not clear at present how the number of active ribosomes depends on growth conditions and the specific organism. Considering the fact that all other parameters in equation 7 are constants and $\mathrm{C}$ is constant, the fraction of active ribosome $\mathrm{F}_{\mathrm{Ra}}$ may not vary significantly among organisms and growth conditions. If we take the number of free ribosomes to equal 15\% (between 10 and 20\%) then the fraction of active ribosomes will be 0.85 .

The $\mathrm{C}$ value was calculated by substituting estimated values of the parameters $\mathrm{M}_{\text {nucl }}, \mathrm{M}_{\mathrm{aa}}, \mathrm{n}_{\mathrm{nucl} \mathrm{R}^{\prime}}, \mathrm{F}_{\mathrm{rRNA}}, \mathrm{F}_{\mathrm{Ra}}$ in equation 7 . The value of $C$, rounded to the nearest 1000 , was 18,000 . This number is close to the $C$ value $(19,630)$ obtained by regressing $R_{\text {RNA:Pr }}$ against $R_{\text {SGR:PER }}$ (Figure 3 ).
In conclusion, the cellular requirement of ribosomes for protein production in microorganisms may be estimated as the RNA:protein ratio using a general constant to characterise protein-synthesis machinery in the cell. This constant is a function of the number of nucleotides per ribosome, the fraction of ribosomal RNA in total RNA, the fraction of active ribosomes in the cell, and the average mass of nucleotide and amino acid.

Considering the proportionality between $\mathrm{R}_{\mathrm{SGR} \text { PER }}$ and $\mathrm{R}_{\mathrm{RNA}: \mathrm{Pr}^{\prime}}$ the ratios PER:SGR and RNA:protein will be also proportional. Therefore, the overall efficiency of protein production in the microorganisms is proportional to RNA:protein. In conclusion, the effect of growth rate on RNA:protein and P:N ratios actually reproduced and, probably, followed the effect of growth rate on the overall efficiency of protein production in the microorganisms.

\section{Discussion \\ Explaining the similarity of RNA:protein and P:N ratios in diverse organisms}

According to equation 6 and Figure 3, the cellular requirement of ribosomes for protein synthesis in both prokaryotes and lower eukaryotes may be calculated from the RNA:protein ratio using the same constant for different unicellular organisms. This emphasizes the similarity in the protein synthesis machinery of different unicellular organisms. Specifically, parameters such as the number of nucleotides per ribosome, the average masses of nucleotides and amino acids, the fraction of ribosomal RNA in total RNA, and the fraction of active ribosomes are similar in unicellular organisms. Conservation of these parameters is consistent with the conservative function of ribosomes. The basic functions of initiation, elongation, and termination in ribosomes of bacteria closely resemble those of eukaryotes. A conservative core of proteins and genes is responsible for the basic "housekeeping" functions of the cell including metabolism, translation, DNA replication and repair, and RNA processing $[30,31]$. This implies a similarity in genomic mechanisms that regulate growth and protein synthesis of organisms in response to environmental changes and, thus, their RNA:protein and $\mathrm{P}: \mathrm{N}$ stoichiometry. The actual biomass $\mathrm{P}: \mathrm{N}$ ratio in organisms is not necessarily equal to the P:N ratio derived from RNA and protein contents. The accumulation of nutrients when there is an excess supply, their reuse, and some other processes may cause significant variation in actual biomass P:N ratios. Averaging the ratios for the organisms among diverse environmental conditions, however, decreases the variation and causes the P:N values to approach cellular growth requirements. It may explain why mean P:N ratios of the microbial species and plants reviewed in the introduction are rather similar to the P: $N$ ratios calculated from RNA and protein contents of the unicellular organism. 
Although taking averages of many species reduces $\mathrm{N}$ and $P$ variance, the estimation of P:N ratios from RNA:protein for some specific organisms and growth conditions may be invalid. Microorganisms in the studies were considered under conditions of balanced growth or glucose limitation (in the case of $S$. ruminantium). Additional studies are needed to investigate if $\mathrm{N}$ and $\mathrm{P}$ limitations have a similar effect on the efficiency of protein synthesis, and RNA:protein and P:N ratios. Although the P:N concentrations of many heterotrophic organisms are largely independent of $\mathrm{P}: \mathrm{N}$ concentrations in the growth media [7], in some microorganisms luxury consumption of nutrients can occur, which could affect the relationships considered in the paper [32]. The relationships for phototrophs and nitrogen-fixing organisms may be even more problematical. Phototrophs have large variations in P:N related to the contents of rubisco and pigments, which vary with light and nutrient supply. In nitrogen-fixing organisms, a large proportion of protein is devoted to nitrogen fixation. Therefore, there is a need for further studies in which both RNA:protein contents and P:N ratios are measured directly and a broader range of organisms and conditions are considered.

\section{Regulation of the cellular efficiency of protein synthesis, RNA:protein and P:N ratios by trade-off between growth and maintenance}

We suggest that the decrease in the cellular requirement of ribosomes for protein production with the increase in cell growth rate reported in this paper may be explained by the disposable soma theory. According to this theory, the metabolic resources are limited in any one organism and may be divided between two main activities, growth/ reproduction and maintenance/survival $[33,34]$. Cellular growth requires a large expenditure of biosynthetic energy in all organisms. Actively growing cells of prokaryotes and low eukaryotes expend around $80 \%$ of total nuclear transcription effort in the assembly of translational machinery. About $10 \%$ of cell proteins are ribosomal, which are mainly involved in stabilization of rRNAs, thereby facilitating the catalytic roles of ribosomes [35,36]. Thus, microbial cells strictly control ribosome biogenesis by quickly adjusting it to particular nutritional conditions [35,37-39]. This adjustment occurs not only by a decrease or an increase of rRNA transcription, but also by degradation of ribosomes under conditions of bacterial starvation, and by formation of $100 \mathrm{~S}$ ribosome dimers, which are believed to be a storage form for ribosomes in the stationary state. As stated in the introduction and demonstrated in this study, the mass of total RNA and rRNA in organisms decreases when growth conditions are impaired. Given the disposable soma theory, it may be hypothesized that the reduction of these synthetic efforts coincides with the redirection of metabolic activity in cells from replication to maintenance, and that this redirection is the main reason for a decrease in the RNA:protein and $\mathrm{P}: \mathrm{N}$ ratios. It is known that, although the activity of "housekeeping" genes involved in ribosome production and other processes related to proliferation decreases in adverse growth conditions, the activity of genes encoding general stress proteins involved in cellular maintenance increases. A long line of evidence supports redirection of this activity in bacteria $[40,41]$.

In conclusion, a stressful environment causes unicellular organisms to conserve cellular resources by directing them into maintenance instead of reproduction. As a result, the decrease in cellular RNA production at slow growth will coincide with a more efficient use of cellular components including ribosomes and synthesized proteins. In combination, these processes decrease the requirement of ribosomes for protein production with decrease in growth rate and, as a result, decrease RNA:protein and P:N ratios.

\section{RNA:protein ratio as a characteristic of P:N stoichiometry of unicellular organisms and their interaction with the environment}

According to the GRH, the main reasons for the positive correlation between P:N stoichiometry of organisms and their growth rate lie in changes in the allocation of cellular resources to the synthesis of ribosomes and ribosomal RNA [6,7]. According to our study, this ecologically important phenomenon may result not only from changes in the production of rRNA, but also from changes in the overall efficiency of protein synthesis. Our findings support the view that, when growth of unicellular organisms is restricted, there is a decrease in the number of ribosomes required to incorporate one amino acid into synthesized protein. These changes decrease RNA:protein ratio in the cell and, therefore, may be responsible for the decrease in P:N stoichiometry of the organism after growth impairment. In support of this mechanism, the $\mathrm{P}: \mathrm{N}$ ratios calculated from RNA and protein contents in the studied unicellular organisms growing in very diverse conditions were in the same range as the mean ratios reported for different microorganisms, and were similarly related to growth rate as stated in the GRH. The strong links among P:N stoichiometry, RNA:protein ratio, ribosomal requirement for protein synthesis, and growth rate of unicellular organisms indicated by the study have ecological implications. The relationships among the parameters may be used to characterize growth rate and the overall efficiency of protein synthesis of the organism by measuring RNA:protein ratio. In a wider context, it may provide a means of elucidating the $\mathrm{N}$ and $\mathrm{P}$ economies of complex ecological systems. An example is the $\mathrm{N}$ and $\mathrm{P}$ economy of soil organic matter. P:N ratios of surface soil organic matter reported in several studies [42-45] are in the same range as the P:N ratio calculated from RNA and protein contents in the studied microorganisms. The 
other example is the average P:N ratio in oceanic waters, which is close to the P:N ratio in marine phytoplankton [1]. This ratio is equal to the canonical Redfield ratio and also lies in the range indicated by the study. It is plausible, therefore, that the cellular RNA:protein stoichiometry, which characterizes the conservative protein synthesis machinery of the cell, has an impact on the average P:N ratios in different environments.

\section{Conclusion}

Results of the study show that the environment of microorganisms affects their growth rate through trade-off between growth and cellular maintenance. The change in the allocation of the cellular resources in response to growth conditions may affect not only the number of synthesized ribosomes in the cell as postulated by the GRH, but also the overall efficiency of protein synthesis in the cell and, therefore, the RNA:protein and P:N ratios of the microorganisms. This regularity may underlie the similarity in the P:N ratios of diverse organisms. The P:N stoichiometry of organisms, in turn, appears to have a decisive influence on the chemical composition of the natural environment.

\section{Methods}

Experimental data used in the study were obtained from the papers referenced in the Table 1 . In all studies except $S$. ruminantium, the organisms were cultured in different growth media supporting their steady state growth at a variety of growth rates. In the case of $S$. ruminantium, a strictly anaerobic ruminal bacterium, the organism was grown in a steady-state continuous culture, under energy (glucose) limitation (as often occurs in the rumen) to control growth rate. No $\mathrm{N}$ or $\mathrm{P}$ limitation was reported in the studies. The number of growth conditions, temperature, and growth rates of the organisms are given in Table 1. The total weights of proteins were determined in alkaline and hot-acid extracts of cells. The total number of RNA and DNA molecules was estimated in the perchloric acid soluble fraction. In studies of E. coli, S. coelicolor, M. bovis, $S$. cerevisiae (two studies) and $N$. crassa, the relative amount of ribosomal RNA in total RNA was estimated by spectroscopic methods or by separating rRNA on a linear sucrose gradient. The number of active ribosomes in these experiments was estimated as polyribosomes. The distribution of ribosomes in polyribosomes and ribosomal subunits in the studies was determined using zonal sucrose gradient centrifugation. PER were calculated from experimentally determined rRNA contents and the fraction of active ribosomes by equations 1 and 2. The mass of total RNA and proteins per cell were used to calculate (i) the ratio between these parameters by mass $\left(\mathrm{R}_{\mathrm{RNA}: \mathrm{Pr}}\right)$, (ii) total $\mathrm{P}$ and $\mathrm{N}$ contents in RNA and proteins per cell, and (iii) the ratio between $P$ and $N$ contents $\left(R_{P: N}\right)$. The calculations were made for each set of growth conditions in order to estimate their effect on $R_{R N A: P r}$ and $R_{P: N}$. The total $\mathrm{P}$ and $\mathrm{N}$ contents were not measured in the studies. We calculated these values from the mean weight percentage of these elements in RNA and proteins [5], namely $15 \%$ nitrogen and $8 \%$ phosphorous in RNA, and $17.2 \%$ nitrogen in proteins.

\section{Abbreviations \\ GRH Growth rate hypothesis}

SGR Specific growth rates

SGR $_{\text {max }}$ Maximum SGR of the organism in the study

RGR Relative growth rate (calculated as SGR divided by $\mathrm{SGR}_{\max }$ )

PER Peptide chain elongation rate

$\mathbf{R}_{\text {SGR:PER }}$ Ratio of SGR to PER

$\mathbf{m}_{\mathrm{RNA}}$ Mass of total RNA

$\mathbf{m}_{\mathrm{Pr}}$ Mass of proteins

$\mathbf{R}_{\mathrm{RNA} \text { Pr }}$ Ratio of $\mathrm{m}_{\mathrm{RNA}}$ to $\mathrm{m}_{\mathrm{Pr}}$

P Total mass of phosphorous per cell

$\mathbf{N}$ Total mass of proteins per cell

$\mathbf{R}_{\mathrm{P}: \mathrm{N}}$ Ratio of $\mathrm{P}$ to $\mathrm{N}$ by mass

$\mathbf{m}_{\text {rRNA }}$ Mass of ribosomal RNA per cell

$\mathbf{F}_{\mathbf{R a}}$ Fraction of active ribosomes

$\mathbf{n}_{\mathrm{aa}}$ Cellular protein content in amino acids equivalents

$\mathbf{n}_{\mathbf{R}}$ Number of ribosomes per cell

$\mathbf{F}_{\text {rRNA }}$ Fraction of ribosomal RNA in total RNA calculated as the ratio $m_{r R N A}$ and $m_{\mathrm{RNA}}$

$\mathbf{N}_{\mathbf{a}}$ Avogadro's constant

$\mathbf{M}_{\text {nucl }}$ Average mass of nucleotide

$\mathbf{n}_{\text {nuclR }}$ Number of nucleotides per ribosome

$\mathbf{M}_{\mathbf{a a}}$ Average mass of amino acid

C Coefficient of proportionality between $R_{R N A: P r a n}$ and $\mathrm{R}_{\mathrm{SGR} \text { PER }}$ 


\section{Authors' contributions}

TK developed the concept underlying the study, analyzed data, developed the theoretical model, and drafted the manuscript. DG contributed to analysis and interpretation of the data. CS and TA participated in the acquisition of data and in the critical revision of the manuscript. All authors read and approved the final manuscript.

\section{Acknowledgements}

We are very grateful to reviewers of the paper whose comments allowed us to improve the manuscript significantly. This study was supported by a grant from the Sustained Agriculture Research and Education program of the US. The work of TK was partially supported by DOE Genomics:GTL grants DOE LAB-04-32 from the US Department of Energy (Office of Biological and Environmental Research, Office of Science).

\section{References}

I. Geider RJ, La Roche J: Redfield revisited: variability in the N:P ratio of phytoplankton and its biochemical basis. Eur J Phycol 2002, 37:1-17.

2. Elser JJ, Fagan WF, Denno RF, Dobberfuhl DR, Folarin A, Huberty A, Interlandi S, Kilham SS, McCauley E, Schulz KL, Siemann EH, Sterner RW: Nutritional constraints in terrestrial and freshwater food webs. Nature 2000, 408:578-80.

3. Knecht MR, Goransson A: Terrestrial plants require nutrients in similar proportions. Tree Physiol 2004, 24:447-460.

4. Gusewell S: N:P ratios in terrestrial plants: variation and functional significance. New Phytol 2004, 164:243-266.

5. Elser J], Dobberfuhl DR, MacKay NA, Schampel JH: Organism size, life history, and N:P stoichiometry: Towards a unified view of cellular and ecosystem processes. BioScience 1996, 46:674-684.

6. Elser JJ, Sterner RW, Gorokhova E, Fagan WF, Markow TA, Cotner JB, Harrison JF, Hobbie SE, Odell GM, Weider LW: Biological stoichiometry from genes to ecosystems. Ecology Lett 2000, 3:540-550.

7. Sterner RW, Elser J): Ecological stoichiometry:the biology of elements from molecules to the biosphere Princeton NJ:Princeton University Press; 2002.

8. Klappenbach JA, Dunbar JM, Schmidt TM: rRNA operon copy number reflects ecological strategies of bacteria. Appl Environ Microbiol 2000, 66:1328-1333.

9. Condon C, Squires C, Squires CL: Control of rRNA transcription in Escherichia coli. Microbiol Rev 1995, 59:623-645.

10. Kerkhof L, Kemp P: Small ribosomal RNA content in marine Proteobacteria during non-steady-state growth. FEMS Microbiol Eco 1999, 30:253-260.

II. Cox RA: Quantitative relationships for specific growth rates and macromolecular compositions of Mycobacterium tuberculosis, Streptomyces coelicolor A3(2) and Escherichia coli B/r: an integrative theoretical approach. Microbiology 2004, I 50: | 4 I3-1426.

12. Mink RW, Hespell RB: Long-term nutrient starvation of continuously cultured (glucose-limited) Selenomonas ruminantium. J Bacteriol 1981, I 48:54|-550.

13. Waldron C, Lacroute F: Effect of growth rate on the amounts of ribosomal and transfer ribonucleic acids in yeast. J Bacteriol Kerkhof L, Kemp 1975:P855-865.

14. Boehlke KW, Friesen JD: Cellular content of ribonucleic acid and protein in Saccharomyces cerevisiae as a function of exponential growth rate: calculation of the apparent peptide chain elongation rate. J Bacteriol 1975, I 2 I :429-433.

15. Alberghina FA, Sturani E, Gohlke JR: Levels and rates of synthesis of ribosomal ribonucleic acid, transfer ribonucleic acid, and protein in Neurospora crassa in different steady states of growth. J Biol Chem 1975, 250:4381-4388.

16. Poyton RO: Effect of growth rate on the macromolecular composition of Prototheca zopfii, a colorless alga which divides by multiple fission. I Bacteriol 1973, I | 3:203-2 I I.

17. Ehrenberg M, Kurland CG: Costs of accuracy determined by a maximal growth rate constraint. $Q$ Rev Biophys 1984, I 7:45-82.
18. Mikkola R, Kurland CG: Selection of laboratory wild-type phenotype from natural isolates of Escherichia coli in chemostats. Mol Bio Evol 1992, 9:394-402.

19. Bremer H, Dennis PP: Modulation of chemical composition and other parameters of the cell by growth rate. In Escherichia coli and Salmonella typhimurium Cellular and Molecular Biology 2nd edition. Edited by: Neidhardt, FC. ASM Press, Washington DC; 1996:1553-1569.

20. Shulman RW, Sripati CE, Warner JR: Noncoordinated transcription in the absence of protein synthesis in yeast. $J$ Biol Chem 1977, 252:1344-1349.

21. Waldron C: Synthesis of ribosomal and transfer ribonucleic acid in yeast during a nutritional shift up. J Gen Microbiol 1977, 98:2|5-22|

22. Ehrenberg M, Bilgin N, Kurland CG: Design and use of a fast and accurate in vitro translation system. In Ribosomes and Protein Synthesis. A Practical Approach Edited by: Spedding, G. New York: Oxford University Press; 1990:101-139.

23. Spirin AS: Ribosome preparation and cell-free protein synthesis. In The Ribosome: Structure, Function And Evolution Edited by: Hill WE, Dahlberg A, Garrett RA, Moore PB, Schlessinger D, Warner, JR. Washington, DC: American Society of Microbiology; 1990.

24. Martin JF, Barreiro C, Gonzalez-Lavado E, Barriuso M: Ribosomal RNA and ribosomal proteins in corynebacteria. J. Biotechnol 2003, I04:4I-53.

25. Bremer H, Dennis PP: Modulation of chemical composition and other parameters of the cell by growth rate. In Escherichia coli and Salmonella typhimurium Cellular and Molecular Biology 2nd edition. Edited by: Neidhardt FC. Washington DC: ASM Press; 1996:1553-1569.

26. Mehra A, Lee $\mathrm{KH}$, Hatzimanikatis $\mathrm{V}$ : Insights into the relation between mRNA and protein expression patterns: I. Theoretical considerations. Biotechnol Bioeng 2003, 84:822-833.

27. Niven GW: Ribosome modulation factor protects Escherichia coli during heat stress, but this may not be dependent on ribosome dimerisation. Arch Microbiol 2004, I 82:60-66

28. El-Sharoud WM, Niven GW: The activity of ribosome modulation factor during growth of Escherichia coli under acidic conditions. Arch Microbiol 2005, 1 84: 18-24.

29. Wada A: Growth phase coupled modulation of Escherichia coli ribosomes. Genes Cells 1998, 3:203-208.

30. Koonin EV: Comparative genomics, minimal gene-sets and the last universal common ancestor. Nat Rev Microbiol 2003, I:I27-136.

31. Koonin EV, Fedorova ND, Jackson JD, Jacobs AR, Krylov DM, Makarova KS, Mazumder R, Mekhedov SL, Nikolskaya AN, Rao BS, Rogozin IB, Smirnov S, Sorokin AV, Sverdlov AV, Vasudevan S, Wolf YI, Yin J], Natale DA: A comprehensive evolutionary classification of proteins encoded in complete eukaryotic genomes. Genome Biol 2004, 5:7.

32. Jonasson S, Michelson A, Schmidt IK, Nielsen EV, Callaghan TV: Microbial biomass $C, N$ and $P$ in two arctic soils and responses to addition of NPK fertilizer and sugar: implications for plant nutrient uptake. Oecologia 1996, I06:507-5I5.

33. Nyström T: Growth versus maintenance: a trade-off dictated by RNA polymerase availability and sigma factor competition? Mol Microbiol 2004, 54:855-862.

34. Westendorp RG, Kirkwood TB: Human longevity at the cost of reproductive success. Nature 1998, 396:743-746.

35. Moss T: At the crossroads of growth control; making ribosomal RNA. Curr Opin Genet Dev 2004, I 4:21 0-217.

36. Martin JF, Barreiro C, Gonzalez-Lavado E, Barriuso M: Ribosomal RNA and ribosomal proteins in corynebacteria. I Biotechnol 2003, I 04:41-53.

37. Paul BJ, Ross W, Gaal T, Gourse RL: rRNA transcription in Escherichia coli. Ann. Rev Genet 2004, 38:749-770.

38. Larson DE, Zahradka $\mathrm{P}$, Sells $\mathrm{BH}$ : Control points in eukaryotic ribosome biogenesis. Biochem Cell Biol 1991, 69:5-22.

39. Lawrence RJ, Pikaard CS: Chromatin turn ons and turn offs of ribosomal RNA genes. Cell Cycle 2004, 3:880-883.

40. Bernhardt J, Völker U, Völker A, Antelmann H, Schmid R, Mach H, Hecker M: Specific and general stress proteins in Bacillus subtilis - A two dimensional protein electrophoretic study. Microbiology 1997, 29:999-1017.

41. Schmid R, Bernhardt J, Antelmann H, Volker A, Mach H, Volker U, Hecker $M$ : Identification of vegetative proteins for a two- 
dimensional protein index of Bacillus subtilis. Microbiology 1997, I 43:99|-998.

42. Nieder R, Benbi DK, Isermann K: Soil organic matter dynamics. In Handbook of Processes and Modeling in the Soil-Plant System Edited by: Benbi DK, Nieder R. New York: The Haworth Press Inc; 2003:345-408.

43. Auten JT: The organic phosphorus content of some lowa soils. Soil Sci 1922, 13:119-124.

44. Walker TM, Adams AFR: Studies on soil organic matter. I. Influence of phosphorus content of parent materials on accumulations of carbon, nitrogen, sulfur and organic phosphorus in grassland soils. Soil Sci 1958, 85:307-318.

45. Williams $\mathrm{CH}$, Williams EG, Scott NM: Carbon, nitrogen, sulphur and phosphorus in some Scottish soils. J Soil Sci 1958, I I:334-346.

Publish with Biomed Central and every scientist can read your work free of charge

"BioMed Central will be the most significant development for disseminating the results of biomedical research in our lifetime. "

Sir Paul Nurse, Cancer Research UK

Your research papers will be:

- available free of charge to the entire biomedical community

- peer reviewed and published immediately upon acceptance

- cited in PubMed and archived on PubMed Central

- yours - you keep the copyright

Submit your manuscript here:

http://www.biomedcentral.com/info/publishing_adv.asp
BioMedcentral 